\title{
The Evaluation of Appropriate Selection Learning Media at Junior High School
}

\author{
Hamsi Mansur ${ }^{1}$, Agus Hadi Utama² \\ ${ }^{1,2}$ Educational Technology Study Program, Faculty of Teacher Training and Education, \\ Universitas Lambung Mangkurat \\ Email: ${ }^{1}$ hamsi.mansur@ulm.ac.id*,2agus.utama@ulm.ac.id \\ ${ }^{*}$ Coresponding Author \\ Article history: received March 23, 2021; accepted April 21, 2021; published April 24, 2021
}

\begin{abstract}
The appropriateness of learning media can help deliver messages from teachers to students become more effective. The selection of suitable learning media requires specific criteria to be precise in choosing a learning media because each learning media should have different characteristics and specifications of usefulness. This study aims to conduct a summative evaluation of the appropriate selection of learning media in junior high schools in Banjarmasin. Learning media evaluated using summative tests, totaling five junior high schools using purposive random sampling. Data analysis techniques in evaluating summative models are conducted descriptively-qualitatively using four model criteria used to evaluate learning media's appropriateness: conformity with the material, conformity with student characteristics, conformity with the student's learning style, and conformity with supporting facilities. The appropriateness of learning media used by teachers in Banjarmasin junior high school shows the category of good or, in other words, teachers have been able to plan, choose, utilize, and use learning media following four models criteria appropriateness learning media. Recommendations of the results study of learning media can be applied in other schools to evaluate the appropriate selection of online learning media during the Covid-19 pandemic.
\end{abstract}

Keywords: Learning Media; Media Selection; Summative Evaluation

\section{Copyright (C) 2021 The Author(s)}

This is an open-access article under the CC BY-SA license.

\section{INTRODUCTION}

Education practitioners, namely teachers, are tasked with being consciously responsible in educating, teaching, and guiding students. A teacher should have the ability to choose and even develop appropriate learning media and organize or manage the classroom to learn optimally and ultimately achieve lifelong learning independence as the ultimate goal of the educational process. Professional teachers carry out their essential duties and functions as tutors, motivators, and facilitators and can choose the suitable learning media (Miarso, 2004). A professional teacher facilitator must choose the appropriate learning media in the learning process because each learning media has different characteristics and specifications. Educational objectives can be achieved optimally, namely: effective, efficient, and meaningful. The learning process that teachers centered on and the selection of learning media that lacks added value in the learning process, the learning media is only used as a complementary tool that causes the learning process does not run optimally. Learning media is not used to support the learning process and not the occurrence of time efficiency in the use of learning media, thus causing learning to be meaningless (Mansur, H., \& Rafiudin, R., 2020). This research objective study discusses how teachers can choose a learning media based on personal experiences and 
Mansur, H. et al. | The Evaluation of Appropriate Selection Learning Media at Junior High School

theoretical studies. However, in carrying out technological, pedagogical, content, knowledge competencies, and teachers must have methodological skills in designing and implementing learning, including the selection, mastery, and use of learning media during the Covid-19 pandemic.

The word "Media" comes from Latin, which is the plural form of "medium", literally meaning intermediary or introduction. Association for Education and Communication Technology (AECT) defines the word media as all forms and channels used for the information process. The National Education Association (NEA) defines the media as all objects that can recovered, seen, heard, read, or discussed along with the instruments used for such activities. While Heinich, Molenda, and Russel (1982) interpret the term media as "the term refers to anything that carries information between a source and a receiver". It should also be stated that learning activities are a process of communication. In other words, learning activities through the media occur when there is communication between the recipient of the message $(P)$ with the source (S) through the media (M). Nevertheless, the communication process itself only happens after there is feedback. Based on the description above, it can be briefly stated that the learning media is a vehicle for channeling messages or learning information (Liu, Y., Tong, Y., \& Yang, Y., 2018). Learning media is part of the learning component and becomes an integral part of the learning process because it must be mastered by every teacher (Chuang, Y.-T., 2014). Following the opinion expressed by Sadiman (2014: 11), the teaching and learning process is essentially a communication process, namely the process of conveying information in the form of knowledge and knowledge from the source of the message, namely teachers through channels or mediation in the form of learning media to the recipients of the message, namely students.

The use of learning media helps the process of delivering messages from teachers to students. The selection of learning media requires using a model of certain principles and criteria to precisely choose an effective, more accessible, and meaningful learning media. The purpose of using learning media is to make it easier for students to help master the learning competencies that have been set (Tafonao, T., Saputra, S., \& Suryaningwidi, R., 2020). This study evaluates the appropriateness of the selection of learning media used by teachers when teaching at Banjarmasin junior high school. The contribution and novelty of this research are to apply a model framework on the criteria and principles of selecting appropriate learning media, especially during the Covid 19 pandemic. The appropriate selection of learning media is based on the criteria model for choosing the right learning media put forward by Susilana, R., \& Riyana, C. (2009: 65), namely: conformity with the material, conformity with student characteristics, conformity with the student's learning style, and conformity with supporting facilities. Model criteria used to assess the appropriateness of the selection of learning media are four, namely conformity with the material, conformity with student characteristics, conformity with students' learning style, and conformity with supporting facilities evaluated summatively. The difference between this study and previous research is the application model appropriateness for selecting learning media during the Covid-19 pandemic with summative evaluation.

Heinich, Molenda, and Russel (1982) in their book "Instructional Media and The New Technologies of Instructions" devised a procedural model called the acronym "ASSURE". This ASSURE model is intended to ensure the effective use of learning media, as shown in figure 1. 
Mansur, H. et al. | The Evaluation of Appropriate Selection Learning Media at Junior High School

\begin{tabular}{|c|l|}
\hline A & Analyze Learner \\
\hline S & State Objectives \\
\hline S & Select Methods, Media, Materials \\
\hline U & Utilize Media and Materials \\
\hline R & Require Learner Participation \\
\hline E & Evaluate and Revise \\
\hline
\end{tabular}

Figure 1. ASSURE Model in Appropriate Selection Learning Media

The model synchronized with ASSURE includes six steps in systematic planning for media use: Analyze Learner Characteristics, State Objectives, Select, Modify or Design Materials, Utilize Materials, Require Learner Response, and Summative Evaluation. In an attempt to utilize the media as a teaching aid Edgar Dale (1970), in his book "Audiovisual methods in teaching," Edgar Dale made classifications by level from the most concrete to the most abstract (Wagner, R. W., 1970). The classification of media known as the "cone of experience" of Edgar Dale and widely embraced in determining the most suitable tools for the learning experience. Concerning the function of learning media, can be emphasized the following: 1) As a means of helping to realize a more effective learning situation, 2) As one component that is interconnected with other components to create the expected learning situation, 3) Speed up the learning process, 4) Improving the quality of the teaching and learning process, 5) Concrete abstract to reduce the occurrence of verbalism disease. The use of right choosing media in learning can arouse new desires and interests, increase motivation and stimulation of learning activities, and even psychologically affect students (Hamalik,1986). Sudjana and Rivai (1992) presented several benefits using media; 1 ) can foster student learning motivation because teaching will attract their attention more; 2 ) the meaning of teaching materials will become clearer so that students can understand and allow the mastery and achievement of teaching objectives; 3 ) teaching methods will be more varied, not solely based on verbal communication through words; and 4) students do more activities during learning activities, not only listening but also observing, demonstrating, doing life, and playing when teaching and learning during the pandemic Covid19 at junior high school, selecting and applying a theoretical study above the appropriateness planning in selecting learning media is an exciting thing to discuss this study, especially mapping with the ASSURE model.

Based on the background of the above problems, researchers formulated several problems that can be identified as follows: 1) What are the factual conditions of the use of learning media by teachers in Banjarmasin junior high school, 2) How is the implementation of the summative evaluation model in the selection of the appropriate learning media used by teachers in Banjarmasin junior high school, 3) Does the selection of learning media used by teachers in Banjarmasin junior high school meet the appropriate criteria. In general, this research aims to provide a summative evaluation model to apply the appropriate of teachers in choosing the optimal learning media in Banjarmasin junior high school. In particular, this study aims to obtain an overview of 1) The actual condition of teachers' use of learning media in Banjarmasin junior high school. 2) Implementation of summative evaluation model to evaluate the appropriateness of learning media used by teachers in Banjarmasin, junior high school. 3) Mapping the appropriate learning media selection based on four criteria of the summative evaluation model used by teachers in Banjarmasin junior high school. 
Mansur, H. et al. | The Evaluation of Appropriate Selection Learning Media at Junior High School

\section{METHOD}

This research is a qualitative research summative evaluation model to find information and mapping about the appropriate of teachers in choosing the suitable learning media. The measure of the appropriateness of learning media is analyzed with four criteria which already mentioned the theory of Susilana, R., \& Riyana, C. (2009: 65), namely: 1) conformity with the material, 2) conformity with student characteristics, 3) conformity with the student's learning style, and 4) conformity with supporting facilities. The suitability of instructional media was evaluated summatively on all subjects, such as science and social studies subjects in junior high schools. The method used is purposive random sampling. The sample of this study was taken randomly but still pays attention to the learning media that has been utilized by teachers so that junior high school teachers who rarely and never even use learning media at all can be ignored (Sugioyono, 2004). The criteria used in sample selection as many as five junior high schools in Banjarmasin which is aimed at that teacher who used to plan, choose, utilize, and put in summative evaluation model following by 4 model criteria appropriateness learning media and ASSURE model.

Data collection techniques are use documentation, observation, and interview techniques. Documentation and observations are used to determine the learning media used by teachers, while interviews to know the learning activities and learning media used by teachers. Data analysis techniques in the summative evaluation are conducted descriptively-qualitatively using model criteria used to evaluate the appropriateness of the learning media following four criteria. The researchers then analyze the qualitative data of this study by describing the data obtained as it is through the triangulation of the data source. The data analysis used is the analysis of interactive model data Miles, M.B. \& Huberman, A.M., quoted from Mansur, H. H., Utama, A. H., \& Mastur, M. (2019) as shown in figure 1 below:

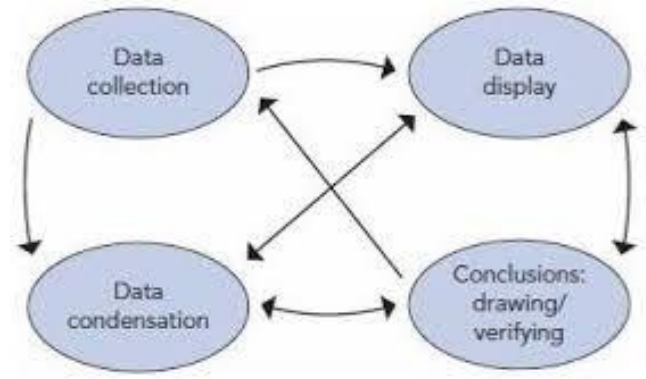

Figure 2. Interactive Model Design Analysis Descriptive-Qualitative Research Method

\section{RESULTS AND DISCUSSION \\ Learning Media Selection Planning}

The model synchronized with ASSURE includes six steps in systematic planning for media use, namely: Analyze Learner Characteristics, State Objectives, Select, Modify or Design Materials, Utilize Materials, Require Learner Response, and Summative Evaluation.

Analyze Learner Characteristics, namely: the identification of students' needs and characteristics. Learning media planning and selection are based on the analysis of learners' needs and learning characteristics (Mansur, H., \& Mastur, M., 2018). One of the indicators of the analysis of the needs and learners' characteristics, namely: teachers have made the selection of appropriate learning media selection that is tailored to the ability to think, attitude, and skills of students who want to be achieved to be mastered easily by students following the demands of the learning curriculum. From the observations of researchers on five junior high schools in 
Mansur, H. et al. | The Evaluation of Appropriate Selection Learning Media at Junior High School

Banjarmasin, it was found that teachers have performed this Analyze Characteristic Learners stage in the process of planning and selecting appropriate learning media.

State Objectives, namely: the formulation of objectives such as SK-KD, indicators, and learning objectives that have been contained in the junior high school lesson plan. The selection of learning media should be made in such a way that it will help and facilitate students to achieve learning goals. The researchers' observations on five junior high schools in Banjarmasin found that the average teacher has implemented learning activities following those in-app junior high schools. In-app also contained materials, media, and learning resources to be used. Based on the results of interviews with teachers of SMPN 1 Banjarmasin found that: "the learning materials and media of wetland learning have not been fully attributed", but in contrast to the results of the interview at SMP IT teacher Ukhuwah Banjarmasin stated that: "for learning, media and materials used have been adapted to the local media in Banjarmasin area, for example in science lessons there is a practice of Herbarium Wetlands".

Select, Modify, or Design Materials, namely: the selecting, changing, and redesigning the appropriate learning media to suit the needs of learning in the classroom. To create or select appropriate learning media in learning activities, teachers will usually do one of the following three possibilities: 1) choose the learning media that is already available, 2) change the existing learning media, and 3 ) redesign the appropriate learning media to fit the learning needs in the classroom. From the researchers' observations on five schools in Banjarmasin, data was found that the average teacher prefers learning media that is already available from the school and facilitated by the school, especially using the internet network to implement online and distance learning. Based on the results of interviews with the teachers of SMPN 4 Banjarmasin, teachers need to utilize technology to support the learning process. Every teacher can develop and utilize learning media. Every school is expected to facilitate it, such as adequate internet access and facilitation for teachers in distance learning systems and students who learn from home.

Utilize Materials, namely: the formulation and structure of materials in the learning media must be related to the substance of the content/subject matter that must be given. The learning media that has been selected in it must contain material that must be mastered by students as contained in the junior high school RPP. From the researchers' observations on five junior high schools, the average teacher is right in composting materials in the learning media consisting of the content of lesson materials, quizzes, practice questions, portfolios, and themed collages. Learning activities conducted to develop fine motor in children and even train children's cognitive by creating a learning environment that attracts students through hybrid learning. Based on the results of interviews with teachers of SMP IT Ukhuwah Banjarmasin, it was found that "college-themed learning media by utilizing digital media such as youtube, Google Classroom, WhatsApp Group, and other Learning Videos. It is very easy for students in the learning period from home and facilitates communication to students to develop creativity".

Require Learner Response: Student involvement in the most effective, efficient, and meaningful learning situation. Teachers control learning situations that allow students to respond and be directly involved in learning. Therefore, students should be involved as possible in using learning media that the teacher has chosen. Based on the observations on five schools in Banjarmasin, the average teacher has engaged students to respond using learning media such as play activities while learning in the quizzes, practice questions, portfolios, and collagethemed. Learning activities conducted to develop fine motor in children and even train children's cognitive by creating a learning environment that attracts students through hybrid learning. Based on the results of an interview with SMP IT teacher Ukhuwah Banjarmasin, it was found 
Mansur, H. et al. | The Evaluation of Appropriate Selection Learning Media at Junior High School

that: "distance learning of science subjects of biodiversity material, students practice herbarium around their homes, taking examples of wetlands, then learning instructions sent through WhatsApp Group and home learning portfolios are sent via Google Classroom".

Summative evaluation, the purpose of learning media evaluation is to choose the suitable learning media to be used in class (Arikunto, S., 1999). This summative evaluation consists of a principle-premise model and four criteria for the precise selection of appropriate learning media. Principle-premise in evaluating learning media is how to manage the evaluation itself consisting of five stages, namely: 1 ) Focus on the evaluation of learning media, 2) design summative evaluation model, 3) collect data/information, 4) analyzing information, and 5) The mapping report of evaluation results.

While designing the summative evaluation in question is to make the criteria for the appropriate selection of the suitable learning media consists of 1) conformity with the material, conformity with student characteristics, conformity with the student's learning style, and conformity with supporting facilities.

\section{The Appropriateness of Learning Media}

Learning using appropriate learning media will run effectively if the role of the teacher in learning is to act as a facilitator or provide students with ease in learning. The learning process by utilizing appropriate learning media to facilitate student learning activities will become more effective, efficient, and meaningful if previously teachers have chosen and prepared appropriate learning media by blending in assure model (Mansur, H., \& Utama, A. H., 2017). Effective, efficient, and meaningful learning can be learning that utilizes or uses appropriate learning media as mediation or a tool in messaging students. Effective, efficient, and meaningful learning must also involve learners interacting directly with their learning media to obtain students' responses to the appropriate learning media that the teacher has chosen.

The appropriate selection of learning media is based on the criteria for choosing the suitable learning media put forward by Susilana, R., \& Riyana, C. (2009: 65), namely: conformity with the material, conformity with student characteristics, conformity with the student's learning style, and conformity with supporting facilities. From the researchers' observations on the suitability of the material, the average teacher chooses many traditional learning media that has been prepared by the school and automatically complies with the learning curriculum contained in the RPP. The formulation and structure of materials in the learning media have also been related to the substance of the content/subject matter to be taught (Harahap, S. B. R., \& Ghofur, M. A., 2020).

Conformity of learning materials is a material or study that will be taught in learning activities. Another consideration of the material or subject matter on the suitability material is the extent to which the depth of the material is presented in the learning media that must be mastered by students. The characteristics of different materials require media that corresponds to the characteristics of students and the learning styles of students are different, so that the suitability of learning materials, characteristics, and learning styles of students is a series of activities in determining the selection and utilization of learning media to be used. Besides, supporting facilities are planning activities before the selection of appropriate learning media. In this planning activity, teachers must weigh the advantages and disadvantages of the facilities and facilities provided by the school, such as the availability of learning media and learning resources that teachers can modify or stay in use (Wijayanti, S., \& Sungkono, J., 2017). 
Mansur, H. et al. | The Evaluation of Appropriate Selection Learning Media at Junior High School

The study result conducted by the researchers found that in a series of activities to select the right learning media for teachers to have done it following the ASSURE model. Either consciously or not, it turns out that teachers have applied the appropriate selection of good and appropriate learning media, ranging from the suitability of materials, students' characteristics, and students' learning style. Supporting facilities are planning activities before the selection of appropriate learning media, here teachers have analyzed the advantages and disadvantages of the facilities and infrastructure provided by the school, namely only benefiting learning media and learning resources, such as Youtube, Google Classroom, Google Meet, WhatsApp Group, Other Learning Videos, PowerPoint, and Zoom Meet in science subjects (Anderson, L. W., Krathwohl, D. R., Airasian, P. W., et al., 2001).

Appropriate learning media is mediation to convey content/material to students to be aroused and respond to the content/material to achieve effective, efficient, and meaningful learning objectives. The selection of appropriate learning media in learning requires in-depth analysis taking into account various aspects needed, such as the ASSURE model. The more relevant the learning media chose, the more supportive it will be in achieving effective, efficient, and meaningful learning objectives (Mansur, H., Utama, A. H., MASTUR, M., \& Rafiudin, R., 2017).

Summative evaluation management is collecting information through assessment activities by using instruments to determine the quality and value of a learning medium. This information will be used as a consideration, solution, and alternative for decision-makers through mapping. Summative evaluation of learning media aims to assess and measure the appropriate learning media chosen by teachers comprehensively. In this case, the researchers focused a summative evaluation on teachers' appropriate selection of learning media. Because when teachers will plan, utilize, and use learning media, the first step is to choose the suitable learning media according to the material, characteristics of students, student learning style, and supporting facilities of the school (Mansur, H. H., \& Utama, A. H., 2019, December). From the results of research and discussion, it can be reported that the results of a summative evaluation of the appropriate selection of appropriate learning media by teachers in Banjarmasin junior high school are as follows table 1.

Table 1. The Mapping Evaluation Appropriateness of Learning Media

\begin{tabular}{|c|c|c|c|c|}
\hline No & $\begin{array}{l}\text { Learning Media Selection } \\
\text { Planning Model }\end{array}$ & $\begin{array}{l}\text { Learning Media Selection } \\
\text { Appropriate Criteria }\end{array}$ & $\begin{array}{c}\text { Percentage } \\
\text { Teachers Who Have } \\
\text { Performed }\end{array}$ & Status \\
\hline \multirow[t]{2}{*}{1} & Analyze Learner & Characteristics of Learners & $80 \%$ & Good \\
\hline & Characteristics & Student Learning Style & $70 \%$ & \\
\hline \multirow[t]{3}{*}{2} & State Objectives & Material Conformity & $100 \%$ & Very \\
\hline & & Characteristics of Learners & $80 \%$ & Good \\
\hline & & Student Learning Style & $70 \%$ & \\
\hline \multirow[t]{2}{*}{3} & Select, Modify, or Design & Material Conformity & $80 \%$ & Good \\
\hline & Materials & Supporting Facilities & $70 \%$ & \\
\hline \multirow[t]{3}{*}{4} & Utilize Materials & Material Conformity & $80 \%$ & Good \\
\hline & & Characteristics of Learners & $80 \%$ & \\
\hline & & Student Learning Style & $70 \%$ & \\
\hline \multirow[t]{2}{*}{5} & Require Learner Response & Characteristics of Learners & $80 \%$ & Good \\
\hline & & Student Learning Style & $70 \%$ & \\
\hline
\end{tabular}


Mansur, H. et al. | The Evaluation of Appropriate Selection Learning Media at Junior High School

\begin{tabular}{lllc}
\hline 6 Evaluation (Summative) & $\begin{array}{l}\text { Teachers feedback after } \\
\text { learning activities are } \\
\text { achieved to reflect on the } \\
\text { improvement of further } \\
\text { learning activities }\end{array}$ & Enough \\
\hline $\begin{array}{l}\text { Average Report of Evaluation Appropriateenes of Learning } \\
\text { Media Used by Teachers at Junior High School Banjarmasin }\end{array}$ & $\geq 80 \%$ & Good \\
\hline $\begin{array}{l}\text { List of Appropriateenes Learning } \\
\text { Media Selection Used by }\end{array}$ & $\begin{array}{l}\text { Other Learning Videos, PowerPoint, and Zoom Meet in Science } \\
\text { Teachers at Junior High School } \\
\text { Banjarmasin }\end{array}$ & subjects. & \\
\hline
\end{tabular}

\section{CONCLUSION}

The actual use of appropriate learning media by teachers in Banjarmasin junior high schools has implemented a good and appropriate learning media planning and selection model following the ASSURE model. The implementation of summative evaluation on the appropriateness of learning media used by teachers in Banjarmasin junior high school shows the good category, or in other words, teachers have been able to plan, choose, utilize, and use appropriate learning media following four model criteria appropriateness of learning media selection.

The mapping appropriateness of learning media results from a summative evaluation in this study conducted based on four model criteria, namely: conformity with the material, conformity with student characteristics, conformity with the learning style of students, and conformity with supporting facilities. Recommendations of the results study of learning media can be applied in other schools to evaluate the appropriate selection of online learning media during the Covid19 pandemic.

\section{REFERENCES}

Anderson, L. W., Krathwohl, D. R., Airasian, P. W., Cruikshank, K. A., Mayer, R. E., Pintrich, P. R., ... Wittrock, M. C. (2001). A Taxonomy for Learning, Teaching, and Assessing: A Revision of Bloom's Taxonomy of Educational Objectives. New York: Addison Wesley Longman, Inc.

Arikunto, S. (1999). Dasar-Dasar Evaluasi Pendidikan. Bumi Aksara.

Chuang, Y.-T. (2014). Increasing Learning Motivation and Student Engagement through the TechnologySupported Learning Environment. Creative Education, 05(23), 1969-1978. https://doi.org/10.4236/ce.2014.523221.

Hamalik, O. (2004). Proses Belajar Mengajar. Bumi Aksara.

Harahap, S. B. R., \& Ghofur, M. A. (2020). Android Based Mind Mapping Learning Media to Improve Students' Understanding of National Income. Indonesian Journal of Instructional Media and Model, 2(2), 126-140.

Liu, Y., Tong, Y., \& Yang, Y. (2018). The Application of Mind Mapping into College Computer The Application of Mind Mapping into College Computer Programming Teaching. Procedia Computer Science, 129, 66-70. https://doi.org/10.1016/j.procs.2018.03.047.

Mansur, H. H., \& Utama, A. H. (2019, December). Challenges and Commitments to Implementation of FullDay School in Banjarmasin. In International Conference on Education Technology (ICOET 2019). Atlantis Press.

Mansur, H. H., Utama, A. H., \& Mastur, M. (2019, December). Pengembangan Media Pembelajaran berbasis Komputer (PBK) Menggunakan Aplikasi Prezi. In Prosiding Seminar Nasional Lingkungan Lahan Basah (Vol. 4, No. 3, pp. 566-569).

Mansur, H., \& Mastur, M. (2018). Implementasi Kurikulum 2013 Dalam Pelaksanaan Pembelajaran Saintifik Dan Tematik Integratif Di SDN Se-Kota Banjarmasin. Jurnal Komunikasi Pendidikan, 2(1), 3241. 
Mansur, H. et al. | The Evaluation of Appropriate Selection Learning Media at Junior High School

Mansur, H., \& Rafiudin, R. (2020). Pengembangan Media Pembelajaran Infografis untuk Meningkatkan Minat Belajar Mahasiswa. Jurnal Komunikasi Pendidikan, 4(1), 37-48.

Mansur, H., Utama, A. H., MASTUR, M., \& Rafiudin, R. (2017). Pemanfaatan Desain Media Ajar Interaktif Dengan Program Microsoft Power Point dan iSpring di Fakultas Keguruan dan IImu Pendidikan (FKIP) Universitas Lambung Mangkurat.

Miarso, Yusufhadi. 2004. Menyemai Benih Teknologi Pendidikan. Jakarta: Kencana.

Molenda, H. R., \& James, D. R. (1982). Instructional Media and The New Technology of Instruction. Canada: John Wiley \& Son.

Sadiman, A. S. (2014). Educational Media, Understanding, Development and Utilization.

Sudjana, N., \& Rivai, A. (2007). Teknologi Pengajaran. Bandung: Sinar Baru Algensindo.

Sugioyono. 2004. Metode Penelitian Manajemen. Bandung: Alfabeta.

Susilana, R., \& Riyana, C. (2009). Media Pembelajaran: Hakikat. Pengembangan, Pemanfaatan dan Penilaian, Bandung

Tafonao, T., Saputra, S., \& Suryaningwidi, R. (2020). Learning Media and Technology: Generation Z and Alpha. Indonesian Journal of Instructional Media and Model, 2(2), 89-100.

Wagner, R. W. (1970). Edgar Dale: Professional. Theory into Practice, 9(2), 89-95.

Wijayanti, S., \& Sungkono, J. (2017). Pengembangan Perangkat Pembelajaran mengacu Model Creative Problem Solving berbasis Somatic, Auditory, Visualization, Intellectually. Al-Jabar: Jurnal Pendidikan Matematika, 8(2), 101-110. 